birds, lespectively), a month after crows have usually arrived or passed through the district, has not been previously recorded. There was little unusual about fall visible migration although large flights of nighthawks (20 and 21 August) and crows (19, 20, 26 September and 8 October) are not recorded every year.

Most of the spring records above were made from four observation points along the South Saskatchewan River. On 35 days between 1 April and 28 May the author spent from one to two hours before 7:00 a.m. at sites one, three and five miles south of Saskatoon and two miles north. The locations were chosen for their proximity to town and because the river is an added attraction to waterfowl and other species. The main requirement for an observation point is as clear a view as possible of distant horizons in all directions. Other spring and practically all fall migrations were detected from York Avenue, or on drives in the country on evenings and weekends.

Predicting these flights is difficult, although the major day-time migrants -hawks, crows and cranes-usually move on a tail-wind. Hawks and eagles in the fall often precede a storm from the northwest. An early morning or late evening flight of shorebirds, waterfowl and other birds is probably the remnant or the vanguard of a night migration.

Because of the restricted period of observation, the temporal pattern of a species' diurnal migration cannot necessarily be determined from the data collected in 1966. One exception may be the hawks. The city of Saskatoon is apparently on a major hawk migration route - for this part of the world. This allows detection of flights throughout the day, particularly by housewives. While most hawk and eagle migrations occur between 10:00 a.m. and 3:00 p.m., there was a "heavy" migration (24 birds) between 6:00 and $7: 25$ p.m. on 14 April. Nighthawks are a species for which significant flights are most frequently recorded when they pass over the city and this year, as in 1964, the largest numbers were seen between 5:00 and 7:30 p.m. (Gollop, Blue Jay 23: 13-14, March, 1965).

It is often difficult to decide whether a bird is making a lengthy migration flight or a shorter local flight. Probably the most important criterion is the direction of flight and the distance over which the direction is maintained. Apparently all species crossing the Saskatoon district during the day fly northwest in spring and southeast in fall. Depending on the species and probably on weather conditions, the spring direction, for example, may vary from almost due west (blackbirds) to north (Evening Grosbeaks). A river or a lake may temporarily change a flock's direction. The number of birds and their height are other criteria useful for some species. In compiling data for this article, many records were rejected because the birds may have been flying to or from roosting or feeding areas or making other local flights. White-headed gulls and ducks are the major problem species in this respect.

Some diurnal migrants have different flight behaviour in spring and fall. For instance, crows in spring begin appearing in the southeast sky as early as 5:30 a.m. and usually continue moving throughout the day, occasionally until 7:00 p.m. On that migration they move out of sight to the northwest as loose flocks of less than 20 birds and as individuals apparently not associated with what is normally considered to be a flock. They usually fly at a constant altitude in a direct line at a steady rate. In fall, however, major migrations are apparently restricted to the period from 10:00 a.m. to 4:00 p.m. The birds are in close-packed flocks of 50 to 1,000 and there is often great variation in altitude. Occasionally there appears to be much confusion or conflict, as evidenced by circling, sailing and temporary changes in direction. On the other hand, hawk migrations have similar characteristics in both directions.

Collections of birds at TV-towers, 
observations of birds moving against the moon and records of birds pausing on migration indicate that night migrants often move simultaneously over wide areas. However, there appears to be little information on daytime migration in the Prairie Provinces. While there is not yet enough data from Saskatoon to define the characteristics of such migrations there, it would be interesting to build up a prairie-wide picture to determine the timing and actual routes of these flights throughout western Canada. The information required for such a Centennial project is date, location and period of observation, weather conditions, route and time of flights, and the numbers of birds and flocks of each species over a period of five years.

\section{REPORT ON BARN OWL AT REGINA}

by H. C. Smith, 1357 Minto St., Regina

At approximately 4:30 p.m. on May 3, $1966 \mathrm{my}$ wife and I were driving north down a dirt road which goes past the west end of the Provincial Correctional Institute east of Regina. Trees line both sides of this road for approximately $1 / 4$ mile, and there were no leaves on the trees at this time. I had stopped the car just prior to turning around when my wife drew my attention to a large light-coloured bird sitting in a tree. I immediately got out and put my field glasses on it. While I was looking at it through my glasses it turned its head toward me. The mottled, cream-coloured back, light cream-coloured breast, and distinctive heart-shaped face identified it as a Barn Owl (Tyto alba). The tree in which the bird was sitting was approximately $25-50$ feet from the car and the bird was approximately 15 feet off the ground. The bird was viewed in good light but, for only a minute before it took flight. As soon as it took flight I checked Peterson's field guide (1961) for confirmation of my identification. The description of the Barn Owl outlined in the guide fit the bird I had just observed.
My wife and I went into the Provincial Correctional Institute grounds and contacted Mr. and Mrs. Al Binnie to ascertain if they had seen this bird. Although they live on the grounds and make regular observations in the area, the Binnies had not previously seen the bird. All four of us then began a search of the trees in the grounds. The bird was flushed on three occasions, but unfortunately the Binnies were never able to observe it while sitting. While in flight this bird appeared to have a long wing span. Although a skilful flier, its wing beat did not seem to be exceptionally strong. The bird gave the impression to me of floating through the air rather than flying.

When Glen Fox (1963) reviewed the occurrences of the Barn Owl in Saskatchewan, he listed records for Saskatchewan as follows: Aylesbury, May 5, 1924; Balcarres. May 1, 1910 ; Kindersley, May 18, 1960. Thus the date of this record for Regina coincides with the dates when this species has previously been seen in Saskatchewan.

This bird is listed as a "straggler" in the Field check-list of Saskatchewan birds, and as "casual" by Peterson (1961). Belcher (1961) has no record of this species for Regina.

R. W. Nero (pers. corresp.) reports the following records for Manitoba: La Rivière, April 8, 1945; Whitewater Lake, October 1927; Sperling, January 1925; and St. Anne's, November 6 , 1912. Salt and Wilk (1966) do not list this species as occurring in Alberta.

\section{LITERATURE CITED}

Belcher, Margaret. 1961. Birds of Regina. Special Publication No. 3, Saskatchewan Natural History Society, Regina.

Fox, Glen. 1963. A possible recent record of the Barn Owl in Saskatchewan. Blue Jay $21: 104$.

Houston, Stuart, Fred G. Bard, and Robert W. Nero. 1959. Field check-list of Saskatchewan birds.

Peterson, Roger Tory. 1961. A field guide to western birds. Houghton Mifflin Company, Boston.

Salt, W. Ray and A. L. Wilk. 1966. The birds of Alberta, second edition. The Queen's Printer, Edmonton. 